Available online at: Http:// http://tsdr.psdku.unpad.ac.id

Tourism and Sustainable Development Review-Journal (TSDR)

ISSN 2722-2152 (online)

Volume 1 Number 2 (2020): 119-134

\title{
Applying a Promotional Mix In Promoting Bujang Valley: A Perspective From Tourists
}

\author{
Kok Shiong Pong 1,2, Ying Shin Chin ${ }^{2}$ \\ 1Univerisiti Putra Malaysia \\ 2Universiti Tunku Abdul Rahman
}

\begin{abstract}
Archaeological tourism received minimal attention from the Malaysian government although many archaeological sites in Malaysia have the potential to attract tourists. The number of tourists to these sites is still not promising. Hence, this study aimed to explore the tourist's perspective on how to promote Bujang Valley as an archaeological destination to stay competitive with other archaeological sites in the region to attract more tourists. 20 visitors were approached through convenience sampling for a semi-structured interview. Each interview session took approximately 30 minutes. Consent was obtained from each visitor before the interview was conducted. The findings showed that the promotion of Bujang Valley is inadequate. Publicity, advertising, and personal selling were among the suggested ways to promote the destination. Also, informants suggested promoting Bujang Valley through ambassador and World Heritage Site status. The research findings were expected to provide suggestions to the federal and local government, travel, and tourism practitioners in marketing communication efforts to attract more local and international tourists. Promotional efforts can be costly, strategic plan on the expenses is necessary to ensure the allocated budget for the promotional efforts is spent optimally to reach the varied audience and create awareness about archaeological sites among different target segment.
\end{abstract}

Keywords: destination marketing; promotional mix; archaeological tourism; Hindu-Buddhism heritage site; Bujang Valley

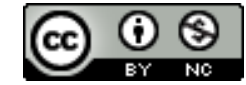

This is an open access article under the CC-BY-NC-SA license.

\section{INTRODUCTION}

Promotion is regarded as an essential motivator for destination marketing organizations (DMOs) as it is often utilized to influence consumer behaviors (Swarbrooke \& Horner, 2007). Promoting a destination is a challenging task because it moves beyond marketing a product or service to marketing an area as a single and unified tourism product (von Friedrichs Grängsjö, 2003). Destination marketing is generally undertaken by DMOs, whose ambit of responsibility and activity are frequently determined by the existing administrative boundaries at different spatial scales (Wang, 2011). Destination marketing involves many stakeholders; and thus, making the process complex and interdependent (Goodall \& Ashworth, 1997). Evans et al. (1995) state that marketing strategy in tourism aims to increase destination competitiveness. The success of a destination depends on its future orientation and alignment of the corresponding resources with the opportunities offered by the external environment (Malachovský \& Királ'ová, 2015). Also, 
Soteriades and Avgeli (2007) add that the process of marketing a destination is more complicated because it involves product development, promotional imaginary enhancement, and market segmentation. They add that destination attractiveness, destination performance, marketing effectiveness, tourism system, and destination competitiveness need to be supported by DMOs. With these elements, it will make the promotional process more efficient.

According to Pike (2008), there is no shortage of ways in which a destination can be promoted and there will be a diverse range of opinions on the strategy that should be employed in every destination community. Promotional activities aim to create demand for a product or service (Goeldner \& Ritchie, 2012). It shows that supply and demand sides are both equally essential where the supply side seeks to stimulate demand for products and services while the demand side refers to people who seek for travel products and services to satisfy certain needs. Boukas (2012) states that most of the studies in archaeological tourism only focus on the supply side while the demand side is being neglected although both sides are closely connected. Chowdhury and Ahmed (2015) further propose the idea of promoting archaeological and historical sites, a proper segmentation, targeting, and positioning plan need to be introduced for the betterment of actual and potential archaeological and historical tourists. Hence, guided by a promotional mix framework, this study is proposed to explore how Bujang Valley can be promoted from the tourists' perspective.

\section{LITERATURE REVIEW}

Promotion, one of the four Ps in the marketing mix is defined as activities that communicate the merits of the product and persuade target customers to buy it (Kotler et al., 2017). Marketers use the different promotional mix to engage with their potential buyers. Marketing campaign usually requires promotional mix from the pre-purchase stage. This effort could help the marketers to notify the public of what is being offered by the marketers. Accordingly, Kim et al. (2009) advise destination managers to maximize their promotional mix to improve their target groups' preferences, value, popularity, and price premiums.

The promotional mix is also known as marketing communications mix, consists of advertising, sales promotion, publicity or public relations, personal selling, and direct and digital marketing (Kotler et al., 2017). Kotler et al. (2017) define the promotional mix components as follow: advertising refers to any paid form of non-personal presentation and promotion of ideas, goods or services by an identified sponsor (p. 342) and aims to target large consumer groups with strong visual images Swarbrooke and Horner (2007); sales promotion is defined as short-term incentives to encourage the purchase or sale of a product or service (Kotler et al., 2017) and aims to encourage the customers to try the product or service for the first time (Swarbrooke \& Horner, 2007, p. 171); personal selling refers to personal presentation by the firm's salesforce for the purpose of making sales and building customer relationships (Kotler et al., 2017) and the purpose is to persuade or coerce potential consumers, or existing consumers to buy more (Swarbrooke \& Horner, 2007, p. 171); public relations is defined as building good relations with the company's various publics by obtaining favorable publicity, building up a good corporate image and handling or pre-empting unfavorable rumors, stories, and events (Kotler et al., 2017) and the objective of public relations is to produce favorable public commentary, stories and rumors about the brand, company and its employees that are not paid for or controlled by the company (Kotler et al., 2017); direct and digital marketing is defined as interacting directly with carefully targeted individual 
consumers and communities to both obtain an immediate response and build lasting customer relationships (Kotler et al., 2017) and it aims to capture information about customers and potential customers from the responses they make to direct calls to action (McCabe, 2009, p. 252).

Promotional tools and strategies aiming to attract the public should be properly and systematically planned to ensure that marketing activities are effective and productive (Masa'deh et al., 2018). Past studies indicated the prominent role of promotion for a product, service, or idea (Qian et al., 2019; Siddhanta \& Banerjee, 2014; Untari et al., 2019). Undeniably, promotion is an excellent way to market a product, service, or idea. Armstrong et al. (2018) state that promotion can attract new buyers and more buying from existing buyers. This is in line with Lake's (2019) perspective where she states that promotion is crucial especially when the product or service is in the introduction phase or when marketers wish to expand the market.

According to Inkson and Minnaert (2018, p. 293), the promotion has an essential role in overcoming the intangible and distant nature of tourism services and in conveying the value that the product or company offers. Promotion is the descriptive term for the mix of communication activities that tourism enterprises, or tourist boards, carry out to influence that public on whom their sales depend (Fletcher et al., 2018, p. 562). For instance, Malaysia experiences a drop in tourist arrivals after the budget for promotions and advertising slashed by Malaysian Ringgit (MYR) 50 million (Spykerman, 2015). It has shown that promotion plays a fundamental role in attracting tourists to visit certain destinations. The basis to make a destination popular is by enhancing the promotion strategies. Kim et al. (2019) conclude that promotion influences satisfaction and behavioral intentions among wine customers. They further suggest that promotion could enhance the management and service marketing of a restaurant. Capik (2019) points out that place promotion has a potentially vital role to play in inward investment-based regional development. This indicates that promotion is significant in a customer's decision-making process and therefore, it should be properly planned to pull different market segments to achieve a higher market share.

To market a destination, Goeldner and Ritchie (2012) indicate that the first step of marketing a destination is to attract attention, secondly, to create interest, thirdly, to create desire and lastly, to take action. The Riviera Maya, the state of Quintana Roo, Mexico records 21.2 million tourists to archaeological sites (Xicotencatl et al., 2017). In Cambodia, Angkor Archaeological Park made a gross revenue of 99 million U.S. Dollars from ticket sales in the year 2019. These achievements come with hard work in selling the respective destination. Nevertheless, the number of tourists at the archaeological sites in Malaysia are still far behind these numbers. Although Lenggong Valley, the archaeological site located at Perak, Malaysia is recognized as World Heritage Site, it is only able to attract a maximum of 6,000 tourists per month while Bujang Valley averagely received 5000 visitors in a month from 2011 to 2013 (Chia, 2017). It shows that destination marketers must strategize their marketing efforts to create awareness about the archaeological sites in Malaysia to attract more domestic and international tourists' arrivals. Promoting the archaeological sites in Malaysia will help the tourism sector grow rapidly with other types of tourism and travel sector. Foxell and Trafford (2010) point out that the heritage and cultural tourism industry, which includes archaeological tourism, has grown steadily in recent years. Hence, aggressive promotion is needed by exploring a preferable source of information from the demand 
side to ensure effective and efficient steps taken to promote a less known Bujang Valley archaeological site to local and international tourists is vital.

In Malaysia, although the contribution from the heritage and cultural tourism is unknown, there is a report showing an increase in the number of tourists at both Malacca World Heritage Site and George Town World Heritage Site after these sites were awarded as World Heritage Site (Tan, 2017). Thus, with the privilege of being awarded as the fourth World Heritage Site in 2012 and as the first archaeological site in Malaysia, Lenggong Valley bears the substantial responsibility to attract tourists. The recognition can make the archeological site attractive to the public if a proper step is taken to ensure that the site is renowned among the public. Consequently, a comprehensive promotional strategy is essential in communicating numerous archaeological sites (i.e. Bujang Valley, Niah Caves, and Bukit Tengkorak) to build destination awareness and popularity. It is hoped that the archaeological sites in Malaysia are comparable to the archaeological sites in our neighboring countries that attract millions of tourists annually. Therefore, allocation of budget to market and necessary promotion of the archaeological sites in Malaysia are deemed imperative. Hence, this study, by taking Bujang Valley as a case study, focuses on tourists' views of the current promotion at Bujang Valley and their suggestions to promote the archaeological site.

\section{RESEARCH METHOD}

Sampling

As mentioned earlier, the objective of this study is to explore the effective promotional ways of Bujang Valley from tourists' perspective. Convenience sampling was utilized where 20 tourists were selected as informants. In the process of data collection, repeated information was found from the first 15 informants, nevertheless, the interview was carried out until the $20^{\text {th }}$ informant to assure that no new theme emerges. This process followed the recommendation by Fusch and Ness (2015) where the sample size is determined when the data reached the saturation point. Despite the repetition of information, the researchers continued the data collection and decided to end the interview process with the 20 th informant where the data saturation point was reached. Also, the sample size was in the suggested range from 5 to 50 informants which were considered sufficient for qualitative studies (Dworkin, 2012).

\section{Study Site}

Bujang Valley was an early center of the Sriwijaya Kingdom during the seventh century CE, it was an important entrepot in the ninth or tenth centuries CE, Bujang valley was the place where Hindu-Buddhist temple structures and artifacts such as statues, stone inscriptions, ceramics, coins, beads, and glass artifacts were found (Chia, 2017). Bujang Valley consisted of various civilizations with a different combination of culture and traditions of the locals (Malays), Indians, Chinese, Srivijayan, Khmer Empire, and West Asia (The ancient Kingdom of Bujang Valley, 2008). Bujang Valley archaeological museum is a very important museum that holds various artifacts found around the valley such as earthenware, Hindu and Buddhist Idols, tools, and jewelry. The surrounding area is rich with evidence of the ancient civilization including stone tools and ancient machinery (The ancient Kingdom of Bujang Valley, 2008). There are four temple structures, as shown in Figure 1 to 4, located in the Bujang Valley Archaeological Museum compound, namely 
Tourism and Sustainable Development Review-Journal (TSDR), Vol. 1 (2), 119-134

Applying a Promotional Mix in Promoting Bujang Valley: A Perspective From Tourists Kok Shiong Pong, Ying Shin Chin

Bukit Batu Pahat Temple, Pendiat Temple, Pengkalan Bujang Temple, and Bendang Dalam Temple. These temple structures were found between the 1930s to 1960s (The ancient Kingdom of Bujang Valley, 2008).

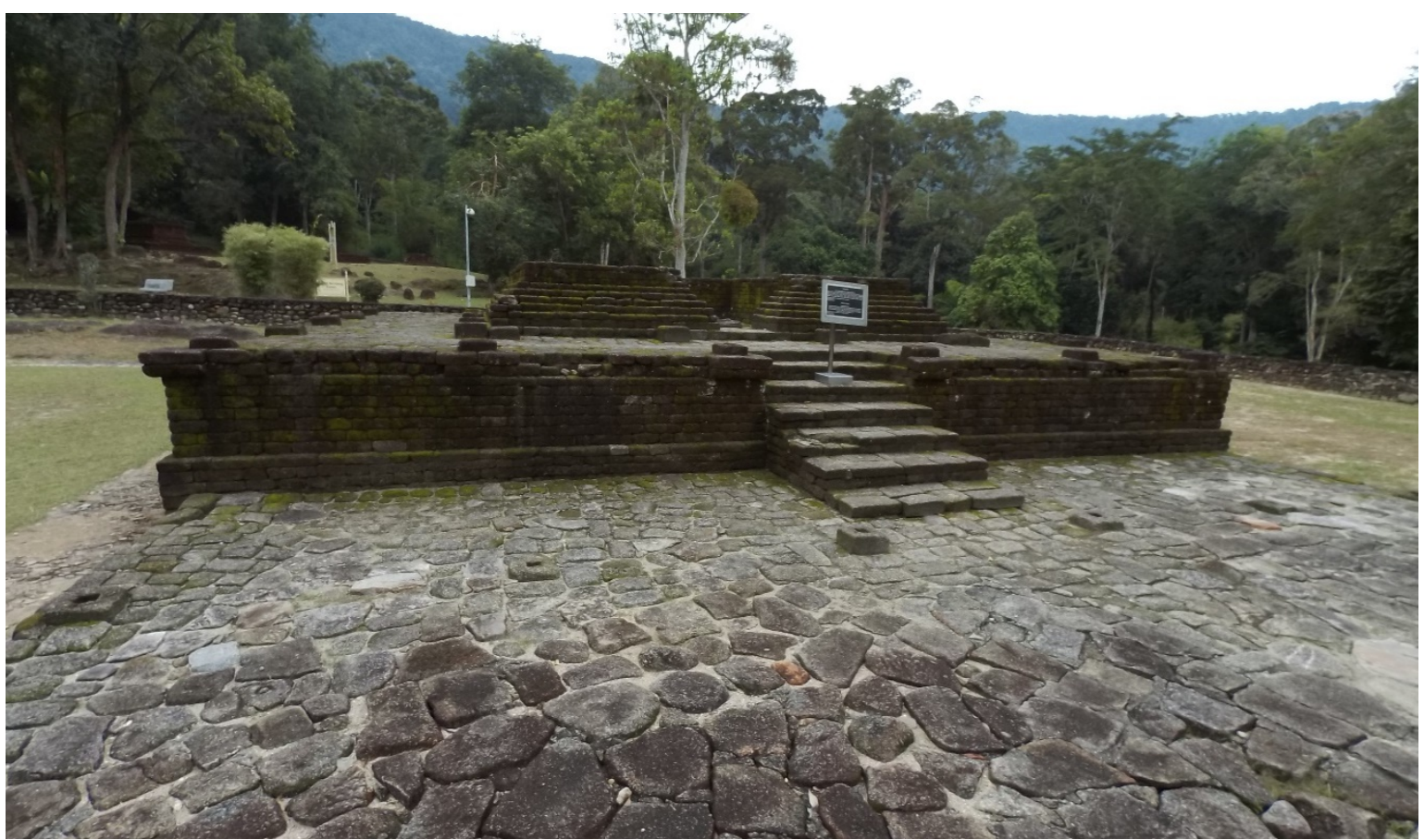

Figure 1. Bukit Batu Pahat Temple

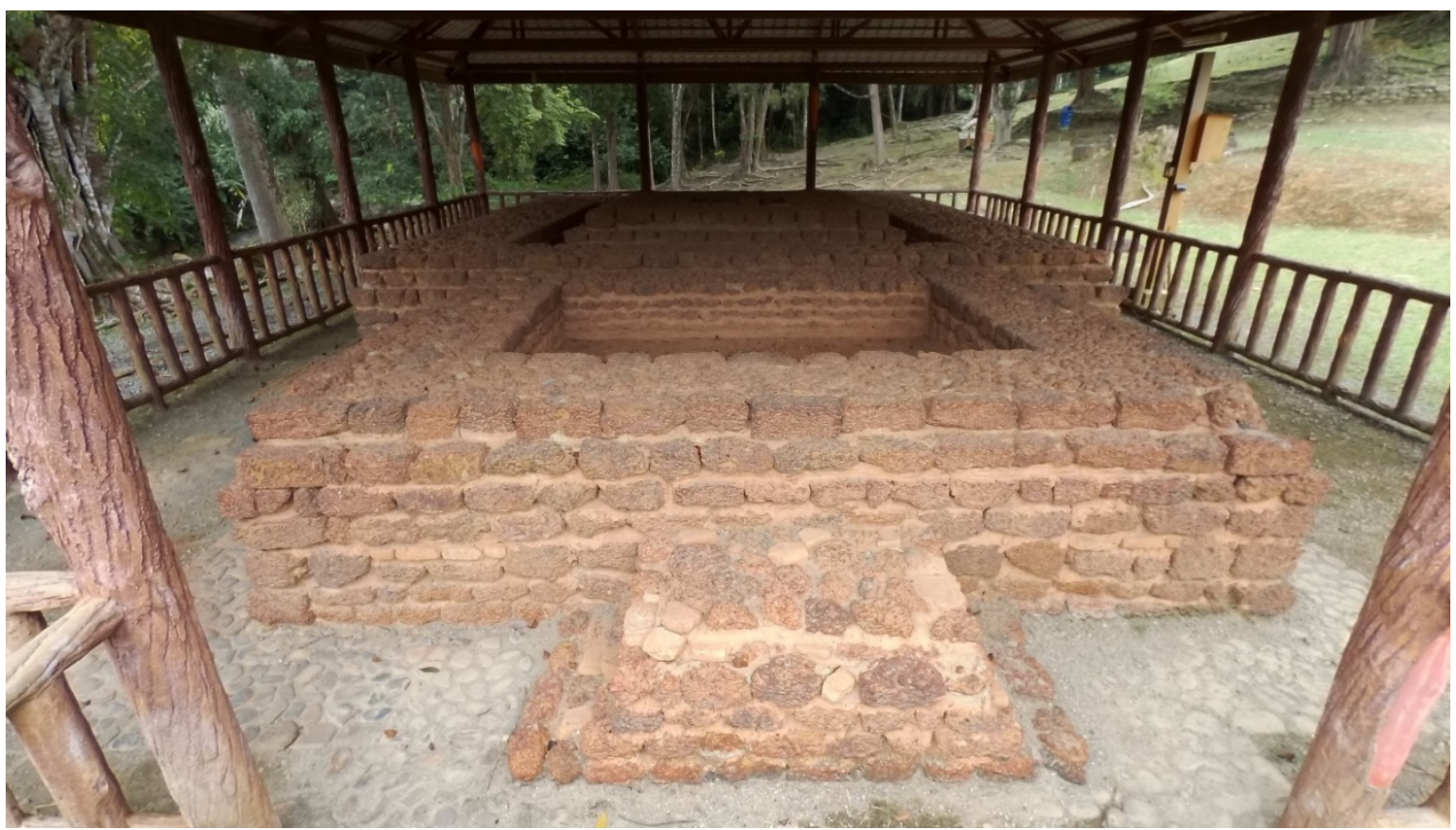

Figure 2. Pendiat Temple 
Tourism and Sustainable Development Review-Journal (TSDR), Vol. 1 (2), 119-134 Applying a Promotional Mix in Promoting Bujang Valley: A Perspective From Tourists Kok Shiong Pong, Ying Shin Chin

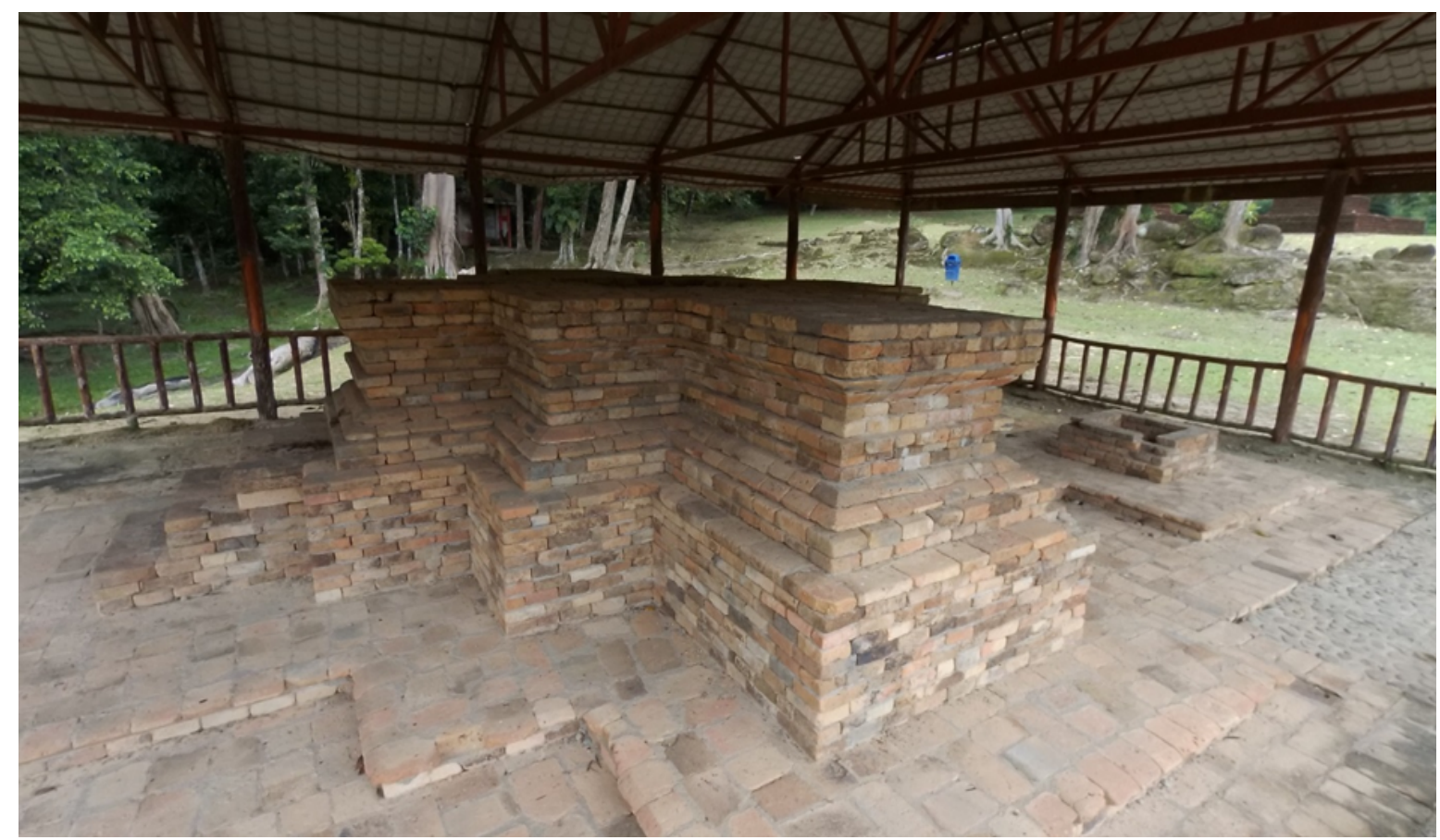

Figure 3. Pengkalan Bujang Temple

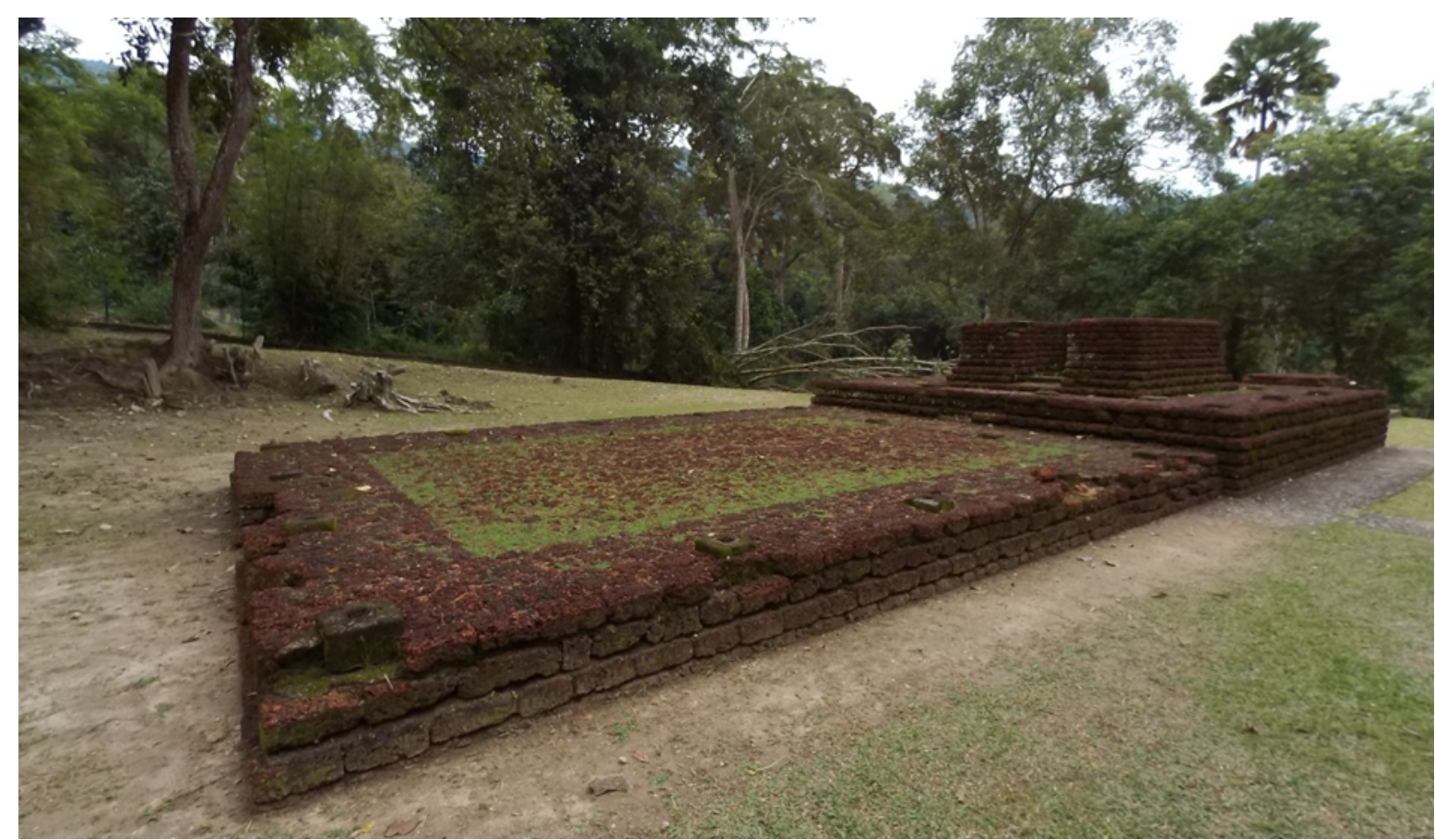

Figure 4. Bendang Dalam Temple

Data Collection and Analysis

This study adopted a qualitative research method in which a semi-structured interview was conducted at the selected archaeological site, Bujang Valley, Kedah for 2 consecutive days in June 
2018. With the written permission from the management of Bujang Valley, researchers approached tourists who visited Bujang Valley site and archaeological museum for a one-to-one interview which averagely took around 30 minutes. Consent was obtained from informants for interviews and tokens of appreciation were given to them after each interview. All interviews conducted in English and Malay were recorded and transcribed verbatim, Malay transcripts were also translated into English before the analysis. The questions that were asked to the informants included their perception of Bujang Valley, the impression towards Bujang Valley, the popularity of Bujang Valley, the source of knowing Bujang Valley, and suggested ways to promote Bujang Valley to local and international tourists. Researchers then conducted a thematic analysis by reading all transcripts carefully and systematically identifying the emerging themes that are related to the ways to promote Bujang Valley (Braun \& Clarke, 2006). The transcriptions were analyzed using a promotional mix framework by Kotler et al. (2017).

\section{FINDINGS AND DISCUSSION}

Demographic Profiles of Informants

The informants were all Malaysians whose ages range from 14 to 61 years old. Among the sample, there were five students, five engineers, two teachers, one housewife and one from different professions such as accountant, logistic manager, farmer, fisherman, geologist, dental surgeon assistant, and interior designer. The majority of the informants travel less than five times a year and most of them visited Bujang Valley for the first time and were accompanied by their friends. Besides, the majority of them got to know about Bujang Valley from textbooks during high school.

Table 1: Demographic Profiles of Informants

\begin{tabular}{llc}
\hline Characteristics & Category & Percentage (\%) \\
\hline Age & Below 20 years old & 15 \\
& $20-29$ & 35 \\
& $30-39$ & 30 \\
& $40-49$ & 10 \\
Gender & 50 years old and above & 10 \\
& Male & 50 \\
Occupation & Female & 50 \\
\multirow{2}{*}{ Traveling experiences in a year } & Working & 75 \\
\multirow{3}{*}{ First time to visit Bujang Valley } & Studying & 25 \\
& Less than five times & 75 \\
Traveling partners & Five times and above & 25 \\
& Yes & 70 \\
& No & 30 \\
& Friends & 45 \\
Source of knowing Bujang Valley & Family & 40 \\
& Spouse & 10 \\
& Alone & 5 \\
& School & 35 \\
& Media & 20 \\
& Friends & 20 \\
& Family & 10 \\
125 & Others & 15 \\
\hline
\end{tabular}


The popularity of Bujang Valley

In the informants' opinions, not all perceived Bujang Valley as famous. Also, some informants provided mixed opinions on the popularity of Bujang Valley.

Lembah Bujang, I guess it is (famous) but probably to a very small extent, not a very wide extent, you see probably if you ask somebody from Johor (one of the Malaysian states with $731 \mathrm{~km}$ drive to Bujang Valley), I don't think they would know Lembah Bujang [Student, 22].

Erm...it is actually for me is famous. People know its name, Lembah Bujang. But...it is not popular. People know the existence of this place but if you ask me, I am 35 now, this is my first visit to this place [Geologist, 35].

Nearly half of the total informants said that Bujang Valley is not well-known, resulting in fewer tourists visiting the site. An informant who visited Bujang Valley more than once said that the destination is less crowded with tourists now as compared to more than a decade ago.

It was famous before, now it is less. If (I) came here, it was full (of people) visiting here, that was in 2007 and 2008, but now less (tourists), not like before, not sure why [Housewife, 27].

Bujang Valley is not famous yet, we didn't see many people visiting here [Farmer, 61].

35 percent of the informants attributed the low popularity of the archaeological destination to inadequate promotion; while one of them said that the destination has a huge need for promotion. One informant commented:

I have never heard of Lembah Bujang anywhere. There's no other way they're promoting this place as far as I'm concerned. I've never seen any other way that they're promoting. You don't get (to see Bujang Valley) on TV, radio, and newspaper, I've never seen any [Student, 22].

Overall, the popularity of Bujang Valley is still considered low. The efforts in boosting the site as a popular destination are required.

\section{Ways to Promote Archaeological Destination}

A variety of promotional ways were suggested by the tourists to promote the destination. Their suggestions were compiled and analyzed as stated in Table 2. Out of the five promotional ways, publicity appeared to be the most frequently suggested way to promote Bujang Valley, followed by advertising and personal selling. The informants also suggested to promote the destination through ambassador and obtaining the World Heritage Site status. 
Table 2: Ways to Promote Bujang Valley and Percentage of Informants with each Way

\begin{tabular}{lc}
\hline \multicolumn{1}{c}{ Ways to promote Bujang Valley } & Percentage of Informants (\%) \\
\hline Publicity & 95 \\
Advertising & 70 \\
Personal Selling & 20 \\
Ambassador & 15 \\
World Heritage Site Status & 10 \\
\hline
\end{tabular}

Publicity

From a pool of suggestions collected, publicity was the most repeated promotional way recommended by the tourists. Most of them who suggested promoting the destination through publicity agreed that social media should be the most strategic tool for this purpose. A female informant said:

Nowadays have Internet, people should promote on Facebook, Instagram, they should use social media. I think it'll help promote the place, so people will notice this place more, they become curious and they'll come and visit, or maybe let them see nice pictures of surrounding (of Bujang Valley) that maybe attract them [Interior Designer, 26].

Another male informant commented:

...put some nice pictures (of Bujang Valley), nice caption, and share on Facebook, that's the best way I think [Engineer, 31].

Informants also pointed out that the government should promote the destination on social media as well. One informant said:

State government Kedah should take a role in promoting because each state has its destinations...Cuti-Cuti Malaysia we usually see the commercial, we need to put up that on Youtube. Portray the available artifacts that are available here. This will attract people to come over here. People love to see these artifacts [Geologist, 35].

While promoting via social media, tourists agreed that organizing events or activities at Bujang Valley can draw public attention to the destination. One informant said:

...maybe they (Management of Bujang Valley) can have something like a show, maybe people will look for the show at the same time have a chance to visit this place (Bujang Valley). It can be a cultural show. Sometimes you can organize a blood donation in this area, so you can attract the people...you are willing to donate at the same time have a chance to visit. Many more things can be done to attract people to come in because most of the people are not aware of it [Transport Operation Manager, 44]. 
Contests can attract audiences and at the same time introduce the destination to them, especially if the contest is at the national or international level. One informant said:

...when you have an event, people will come and see, so many things like a contest they can do, people will definitely come and visit the (archaeological) museum and go back with some knowledge, this kind of thing management can do [Student, 22].

A lot of efforts have to be put in to attract people especially those who are lack interest in history and archaeology. One informant said:

Need to make something different to popularize this destination, maybe invite artists to the concert to attract more teenagers [Engineer, 29].

Bujang Valley was suggested to be one of the destinations to be promoted in the "Visit Malaysia Year" campaign of Tourism Malaysia. The Malaysian government should ensure the Tourism Malaysia website provides adequate information about Bujang Valley. One informant said:

Before I come here, I go to Tourism Malaysia website, I tried to find about Kedah (Malaysian state where Bujang Valley is located in) what is the place to see, but there's nothing about Bujang Valley. Lack of information can make people no information can get [Engineer, 35].

\section{Advertising}

Informants suggested that the DMOs should allocate a budget to have a constant promotion through advertisements, they believed that advertisement is essential in disseminating messages and information about the site domestically and internationally. Also, they suggested the government and Bujang Valley management consider the possibility of advertising the archaeological site through various media such as traditional media (television, radio, newspaper, a magazine on the flight) and the Internet. At the same time, the main intention is primarily to expose the destination to the public.

Informants suggested the information placed on advertisements must be sufficient to encourage people to visit the destination. Informants suggested:

...you can explain the location of here (Bujang Valley) in an advertisement, what is Bujang Valley? Why is it famous? What is so famous about Bujang Valley? What can you identify here? What are the things you can see here? And what is so special about it? So you give some explanations to people, (they) also have the interest to find out [Transport Operation Manager, 44].

...do more advertisements through website...newspaper also can (and include information) about what inside there, what facilities here. Just a simple advertisement, I think this is the best way to reach the people [Engineer, 35]. 
Although information about the destination is essential, visuals on advertisements also play an important role to attract potential tourists. One informant said:

...more advertisements on TV and more banners, don't be only words, but visuals of artifacts will be more attractive [Engineer, 29].

Personal Selling

Informants suggested having a tour package for Bujang Valley, the management of the archaeological destination can collaborate with tour agencies to initiate a one-day trip package with travel guide at few tourists' spots for tourists who travel to Kedah. Also, state or local governments should join travel fair organized locally or internationally to sell the tour package to the public. One informant said:

Can provide a package including visiting Bujang Valley and Gunung Jerai (Mount Jerai located in Kedah), so that if you go to Kedah can visit few places [Engineer, 29].

The one-day trip package can also encourage schools to initiate a study tour for students to Bujang Valley. One informant suggested the Ministry of Education assist with this.

Ambassador

The findings suggested that certain individuals should be given attention in promoting Bujang Valley as they may play a key role in encouraging or urging others to visit the destination.

People or archaeologists from other countries (DMOs) should invite them, ask them (archaeologists) to take a look, ask them (DMOs) to involve international people... they will go back and promote to the people from their place, so people from there, they will come they want to visit [Student, 22].

Look for the descendants of the early settlers (of Bujang Valley), tell them (about this place), maybe they will come over in a big group [Farmer, 61].

Ministry should make the country ambassador pass the information to their country so that they can promote it when they are back (to their home country) [Student, 23].

\section{World Heritage Site}

Being inscribed as a World Heritage Site was seen useful in promoting the destination. However, respondents raised the concern of the challenges Bujang Valley might be facing to be recognized as a World Heritage Site as the status requires some criteria.

Of course, you have to get it recognized by UNESCO (United Nations Educational, Scientific, and Cultural Organization). Apply for the World Heritage Site status. This will be very helpful to let people from all over the world to know about this place like 
Angkor Wat. We no need to go far to visit the archaeological site and this will attract many people to come here [Engineer, 33].

\section{CONCLUSION}

The focus of the study was on archaeological destination promotion. This section discusses the three most frequently suggested ways to promote Bujang Valley by tourists, which include publicity, advertising, and personal selling based on the promotional mix framework. Likewise, this section also discusses the extended promotional mix i.e ambassador and World Heritage Site status which were emerged in the current study. To achieve destination awareness, prospective tourists have to be given adequate and interesting information about the destination to encourage them to visit (Cayron, 2017). However, the interviews with Bujang Valley tourists showed that the government and the management of the archaeological destination did not promote Bujang Valley sufficiently to the public, resulting in the low awareness of the destination. This is similar to Tabon Cave Complex in the Philippines where its weak tourism performance was attributed to the lack of destination awareness (Cayron, 2017).

As a means of attempting to create awareness, improve image, and/or persuade viewers to visit their destination, DMOs often rely on two different forms of persuasive communication which are found within the promotional mix: advertising and publicity; specifically, travel brochures and travel articles. DMOs should take proactive steps to ensure the public is aware of a particular destination as awareness is the first component that greatly affects a customer's buying decision. Thus, publicity, advertising, personal selling, and so on play a crucial role in creating destination awareness and developing a positive destination image in the competitive market. Organizing programs or events is deemed effective to gain public visibility of Bujang Valley. Events can lead to extensive media coverage of a destination (Candrea \& Ispas, 2010; Oklobdžija, 2015). For example, sport event such as the Olympic Games is a good way to promote a country and attract tourists as well as establish a favorable image of the country (Oh, 2002). Oklobdžija (2015) added that events are not only able to contribute to the creation of destination image, but also help promote, position, and brand the destination.

Also, publicity through social media is getting substantial. More than 90 percent of Malaysians whose ages range from 15 to 49 years old are using traditional media as well as digital media (State of the media - The Malaysian media landscape in 2017). Digital media, especially social media cover a considerable part of the Internet search results in which search engines will more likely direct tourists to social media, this shows that tourists are generally relying on social media as a source of information of the destinations when they are planning for a vacation (Xiang \& Gretzel, 2010). Social media is effective in destination promotion due to its ability to create brand awareness, brand engagement, word of mouth, and friends/liking (Bloem, 2012). For instance, Facebook has the features to allow people to leave comments on posts and share with others, the Ministry of Tourism and Culture (MOTAC) Kedah Office can utilize this information sharing platform to expose Bujang Valley to the local and foreign prospective tourists by sharing pictures and videos.

Praveen Kumar (2014) asserted that media and tourism are both service industries and they need to collaborate to reach the wider public locally and internationally. The government and the management of Bujang Valley can promote the archaeological site through advertisements in 
different media platforms such as newspapers, television, and radio, even personalized advertisements in social media would also target the public directly about a destination. This is agreed by Salehi and Farahbakhsh (2014) who claimed that the tourism industry should use advertisements as the main tool for promotion. Ely (2013) contended that repetitive advertisements can leave a positive impression of a destination to prospective consumers.

Personal selling by aggressively pushing the sales of tour package was also suggested to help promote Bujang Valley. A package tour refers to a vacation in which the components of transportation, accommodation, sightseeing, and food are combined and sold to potential or prospective customers at a single price (Sheldon \& Mak, 1987). The tour package should be included on the website like how the destination marketer of Machu Pichu doing it. This will encourage potential tourists to buy the tour package directly from the website. Tourists these days are looking for the aspect of convenience throughout a package tour (Duke \& Persia, 1994) as it serves as an effective means for tourists to visit different tourist spots on a trip with reliable and convenient services (Çetİn et al., 2017). Based on the findings of the study, informants claimed that they were not aware of tourist destinations in the Kedah state, particularly Bujang Valley. Therefore, the initiation of tour package in Bujang Valley is expected to increase the awareness of archaeological destinations among prospective tourists especially those who do not know any tourism destination and the locations in a particular country. The management of Bujang Valley can collaborate with DMOs such as tour agencies to offer different packages for different market segments such as international tourists, local tourists, and students at different travel and tourism fairs like ITB Berlin or Malaysian Association of Tour and Travel Agents Fair.

Other than publicity, advertising, and personal selling, Malaysia Tourism Promotion Board (MTPB) and state government should diversify the promotional ways to make Bujang Valley a competitive destination choice among tourists. As pointed out by our informants, ambassador and World Heritage Site status can be a useful strategy to draw more tourists. The role of ambassador has been widely used in marketing to promote products and services. MTPB should organize tours for all ambassadors from different countries. This will enable the ambassadors to experience the destination. The effort should continue by providing them publicity material of Bujang Valley so that they can disseminate the information about Bujang Valley to their respective countries. Also, world-renowned archaeologists should be invited to Bujang Valley. With the wide-ranging networking with archaeologists from around the world, it can further help create awareness of Bujang Valley. Bujang Valley is considered one of the significant excavations for archaeologists in Southeast Asia. If a gathering of all archaeologists at Bujang Valley annually or bi-annually, this will indeed enhance the reputation of Bujang Valley. Furthermore, to effectively promote Bujang Valley, our informants also suggested the government apply for World Heritage Site status from UNESCO to attract more tourists. A destination being designated as a UNESCO site is positively perceived by the public and therefore significantly influences tourists' choices (Pavlić et al., 2020; Remoaldo et al. 2014). This is in line with the effort by National Heritage Department where it is now advocating UNESCO to inscribe Bujang Valley as the World Heritage Site. If this is successful, it has the potential to draw tourists to the site and bring economic impact to the local community.

DMOs - MTPB and MOTAC Kedah Office are presented with few takeaways from this study. Corporate Communication Department in MTPM and MOTAC Kedah Office should take a proactive role to ensure Bujang Valley is known by the local and international tourists through an integrated 
marketing campaign by taking the opinions from the demand side into consideration. The minimal promotion was the identified factor of the low destination awareness of Bujang Valley, hence, advertisements should be in place when the school holiday or festive season is near. This can generate attention from the public and eventually draw visitation. Also, DMOs should optimize the tour package to international tourists during the holiday season. Furthermore, publicity can be strengthened. through various activities. For example, the government should seek a chance to organize an international archaeological day at Bujang Valley to lure tourists' arrivals. By having such activity, it would further create word of mouth from the tourists that visited the site and enhance the destination awareness and destination image. Utilizing social media for instance Facebook, Youtube, and Instagram will be a good idea. \#Bujangvalley Online Campaign and win prizes for visitors with the most creative way of enhancing the destination knowledge should take place continuously. Subsequently, the destination manager should also engage with social media influencers. Social media influencers have a prevailing effect on its followers. Working with them is a bonus to create awareness of a destination. Next, we also urge the state government and federal government to expedite the process of applying the World Heritage Site status for Bujang Valley. This will be a feather in the cap for Bujang Valley if the destination is successful to obtain the status.

In conclusion, to compete with other archaeological destinations around the world, the state government and MOTAC Kedah Office should put extra effort into promoting Bujang Valley. The stakeholders should intensify the promotion through various media which have a considerably higher reach in Malaysia to ensure an increasing number of tourist arrivals in the local archaeological destinations. The Bujang Valley where it is full of tangible and intangible heritage, if proper planning is in place to promote the destination, it has the potential not only to attract local tourists but also international tourists to visit this mysterious archaeological site which is older than Borobudur in Indonesia and Angkor Wat in Cambodia.

\section{LIMITATION \& FURTHER RESEARCH}

This current study is not free from limitations. There are three limitations to this study. Firstly, data collection was conducted during the off-peak season. Therefore, the informants were limited to the local tourists. Future research can consider interviewing during the peak season when international tourists are available so that the study can look into different perspectives from international tourists. Secondly, the tourist perception of archaeological destination is understudied in the tourism literature, future research can consider studying tourists' perception of Bujang Valley which can be a possible factor contributing to its low popularity. Last but not least, the current study only investigated the suggestions on effective promotional ways to create destination awareness. Future study is encouraged to examine the effort in promoting archaeological sites in Malaysia at different media platforms and how these archaeological sites are being portrayed on media through content analysis.

\section{REFERENCES}

The ancient Kingdom of Bujang Valley. (2008). Tourism Malaysia Retrieved 31 May 2018 from https://www.tourism.gov.my/media/view/the-ancient-kingdom-of-bujang-valley-1. Armstrong, G., Adam, S., Denize, S., Volkov, M., \& Kotler, P. (2018). Principle of Marketing. Pearson Education. 
Bloem, M. V. (2012). Social media strategy in the tourism industry: Formulation and implementation. Master's thesis,. http://essay.utwente.nl/62508/1/MSc_M_van_Bloem.pdf

Boukas, N. (2012). "Young faces in old places": perceptions of young cultural visitors for the archaeological site of Delphi. Journal of Cultural Heritage Management and Sustainable Development, 2(2), 164-189. https://doi.org/10.1108/20441261211273653

Braun, V., \& Clarke, V. (2006). Using thematic analysis in psychology. Qualitative Research in Psychology, 3(2), 77-101. https://doi.org/10.1191/1478088706qp063oa

Candrea, A. N., \& Ispas, A. (2010). Promoting tourist destinations through sport events. The case of Braşov. Revista de turism-studii si cercetari in turism(10), 61-67.

Capik, P. (2019). Foreign Investment Promotion. Springer.

Cayron, J. G. (2017). Archaeological heritage tourism in the Philippines: Challenges and prospects. In P. G. Gould \& K. A. Pyburn (Eds.), Collision or collaboration (pp. 89-102). Springer.

Çetİn, G., Akova, O., Atsİz, O., \& Balık, M. (2017). Components of package tour quality. Conference proceedings, 7th Advances in Hospitality \& Tourism Marketing \& Management (AHTMM) Conference, Famagusta, Cyprus, 10-15 July 2017,

Chowdhury, S. A., \& Ahmed, M. S. Archaeological and Historical Tourism: An Emerging Dimension for the Tourism Industry of Bangladesh.

Duke, C. R., \& Persia, M. A. (1994). Effects of Distribution Channel Level on Tour Purchasing Attributes and Information Sources. Journal of Travel \& Tourism Marketing, 2(2-3), 37-56. https://doi.org/10.1300/J073v02n02_04

Dworkin, S. L. (2012). Sample Size Policy for Qualitative Studies Using In-Depth Interviews. Archives of Sexual Behavior, 41(6), 1319-1320. https://doi.org/10.1007/s10508-0120016-6

Ely, P. A. (2013). Selling Mexico: Marketing and tourism values. Tourism Management Perspectives, 8, 80-89. https://doi.org/https://doi.org/10.1016/j.tmp.2013.07.003

Evans, M. R., Fox, J. B., \& Johnson, R. B. (1995). Identifying Competitive Strategies for Successful Tourism Destination Development. Journal of Hospitality \& Leisure Marketing, 3(1), 37-45. https://doi.org/10.1300/J150v03n01_04

Foxell, E., \& Trafford, d. (2010). Repositioning Malta as a cultural heritage destination. International Journal of Culture, Tourism and Hospitality Research, 4(2), 156-168.

Fusch, P., \& Ness, L. (2015). Are We There Yet? Data Saturation in Qualitative Research. Qualitative Report, 20, 1408-1416.

Goeldner, C. R., \& Ritchie, J. R. B. (2012). Tourism: principles, practices, philosophies.

Goodall, B., \& Ashworth, G. (1997). Marketing in the tourism industry: Promoting tourists' Destinations. Routledge.

Kim, S. H., Han, H., Holland, S., \& Byon, K. (2009). Structural relationships among involvement, destination brand equity, satisfaction and destination visit intentions: The case of Japanese outbound travelers. Journal of Vacation Marketing, 15, 349-365. https://doi.org/10.1177/1356766709335835

Kotler, P., Bowen, J. T., Makens, J., \& Baloglu, S. (2017). Marketing for hospitality and tourism.

Lake, L. (2019, 28 October). Planning a successful promotional campaign. The Balance Small Business. http://thebalancesmb

Malachovský, A., \& Királ'ová, A. (2015). Invigorating the Destination's Marketing Strategy? (The Case of Slovakia). Procedia - Social and Behavioral Sciences, 175, 393-400. https://doi.org/https://doi.org/10.1016/j.sbspro.2015.01.1215

Masa'deh, R. e., Alananzeh, O., Tarhini, A., \& Algudah, O. (2018). The effect of promotional mix on hotel performance during the political crisis in the Middle East. Journal of Hospitality and Tourism Technology, 9(1), 33-49. https://doi.org/10.1108/JHTT-02-2017-0010

Oh, I. (2002). Effective tourism marketing approaches to sporting events: Lessons from 2002 World Cup. Journal of Sport Tourism, 45-67. 
Oklobdžija, S. (2015). The role of events in tourism development. BizInfo Journal, 6(2), 83-97.

Pavlić, I., Puh, B. i Mišković, Lj. (2020). The perception of travellers and the World Heritage Site image. Tourism: An International Interdisciplinary Journal, 68 (2), 181-194. https://doi.org/10.37741/t.68.2.6

Pike, S. (2008). Destination marketing: An integrated marketing communication approach. Butterworth-Heinemann.

PraveenKumar, S. (2014). Role of media in the promotion of tourism industry in India. Global Review of Research in Tourism, Hospitality and Leisure Management (GRRTHLM), 1(3), 187-192.

Qian, C., Wu, C.-F., Zhang, Z., \& Huang, H.-Y. (2019). A study on the promotional mix of pre-service in the view of service design. Industrial Management \& Data Systems, ahead-of-print. https://doi.org/10.1108/IMDS-08-2018-0331

Remoaldo, P. C., Ribeiro, J. C., Vareiro, L., \& Santos, J. F. (2014). Tourists' perceptions of world heritage destinations: The case of Guimarães (Portugal). Tourism and Hospitality Research, 14(4), 206-218. https://doi.org/10.1177/1467358414541457

Salehi, H., \& Farahbakhsh, M. (2014). Tourism advertisement management and effective tools in tourism industry. 3, 124-134.

Sheldon, P. J., \& Mak, J. (1987). The Demand For Package Tours: A Mode Choice Model. Journal of Travel Research, 25(3), 13-17. https://doi.org/10.1177/004728758702500304

Siddhanta, S., \& Banerjee, N. (2014). The impact of promotional mix on profit in the B2B sector. Marketing Intelligence \& Planning, 32(5), 600-615. https://doi.org/10.1108/MIP-052013-0074

Soteriades, M., \& Avgeli, V. A. (2007). Promoting tourism destinations: A strategic marketing approach. Tourism, 55, 335-345.

Spykerman, N. (2015, 17 Aug). Advertising budget cut causing fewer tourists arrivals, say industry players. The Star. https://www.thestar.com.my/News/Nation/2015/08/17/Poorpromos-poor-returns-Advertising-budget-cut-causing-fewer-tourists-arrivals-sayindustry-players/

State of the media - The Malaysian media landscape in 2017. Nielsen Research Retrieved 1 Jul from http://www.nielsen.com/my/en/insights/reports/2018/state-of-the-mediamalaysian-media-landscape-2017.html

Swarbrooke, J., \& Horner, S. (2007). Consumer behaviour in Tourism (2nd ed.). ButterworthHeinemann.

Tan, D. (2017, 11 Dec). Higher tourist arrivals in Penang. The Star. https://www.thestar.com.my/business/business-news/2017/12/11/higher-touristarrivals-in-penang

Untari, R., Avenzora, R., Darusman, D., \& Sunarminto, T. (2019). Community Responses to Naturebased Tourism Promotion Materials in Indonesia. Jurnal Manajemen Hutan Tropika, 25(1), 17-27. https://journal.ipb.ac.id/index.php/jmht/article/view/24909

von Friedrichs Grängsjö, Y. (2003). Destination networking: Co-opetition in peripheral surroundings. International Journal of Physical Distribution \& Logistics Management, 33(5), 427-448. https://doi.org/10.1108/09600030310481997

Wang, Y. C. (2011). Destination marketing and management: scope, definition and structures. In (pp. 1-20). CABI. https://doi.org/10.1079/9781845937621.0001

Xiang, Z., \& Gretzel, U. (2010). Role of social media in online travel information search. Tourism Management, 31(2), 179-188. https://doi.org/https://doi.org/10.1016/j.tourman.2009.02.016

Xicotencatl, R. I. F., Leyva, A. M. V., \& Palafox-Munoz, A. (2017). Archaeological tourism alternative for local development in the Riviera Maya, Quintana Roo. Cuadernos de Turismo 40, 669671. 